\title{
Laron syndrome with immunodeficiency
}

INSERM

\section{Source}

INSERM. (1999). Orphanet: an online rare disease and orphan drug data base. Laron

syndrome with immunodeficiency. ORPHA:220465

This syndrome is characterized by severe growth retardation associated with immunodeficiency. 